E-JURNAL EKONOMI DAN BISNIS UNIVERSITAS UDAYANA
Available online at https://ojs.unud.ac.id/index.php/EEB/index
Vol. 10 No. 10, October 2021, pages: 859-872
e-ISSN: 2337-3067

\title{
PENGARUH LITERASI KEUANGAN, LITERASI DIGITAL, DAN KEMUDAHAN PENGGUNAAN TERHADAP PENGGUNAAN MOBILE BANKING BCA, BNI, BRI
}

\author{
Krissandi Tunggal Pradini ${ }^{1}$ Susanti $^{2}$
}

Article history:

Submitted: 27 April 2021

Revised: 31 Mei 2021

Accepted: 15 Juni 2021

\section{Keywords:}

Digital Literacy;

Ease of Use;

Financial Literacy;

Use of Mobile Banking;

\section{Kata Kunci:}

Literasi Digital;

Kemuahan Penggunaan;

Literasi Keuangan;

Penggunaan Mobile Banking;

\section{Koresponding: \\ Fakultas Ekonomika dan Bisnis Universitas Negeri Surabaya, Jawa Timur, Indonesia \\ Email: \\ krissandi.17080304094@mhs. unesa.ac.id}

\begin{abstract}
The rapid development of technology makes changes in life, one of which is the activity in making transactions, namely by using mobile banking. Mobile Banking is a type of service facility to perform transcations through smartphones. The purpose of this study is to find out the influence of financial literacy, digital literacy and ease of use affect the use of mobile banking BCA, BNI, BRI. This type of research is descriptive quantitative research. The research population is students of Accounting Education Surabaya State University. The research sample uses purpose samples with active student criteria and has mobile banking BCA, BNI and BRI. Data collection using tests and questionnaires in googleform with multiple linear analysis. The results of this study show that (1) Financial Literacy partially has no significant effect on the use of mobile banking. (2) Digital literacy has no partial significant effect on the use of mobile banking. (3) Partial ease of use has a significant effect on the use of mobile banking. and (4) Financial Literacy, Digital Literacy and Ease of Use simultaneously have a significant impact on the use of mobile banking.
\end{abstract}

Abstrak
Perkembangan teknologi yang cukup pesat membuat perubahan
dalam kehidupan salah satunya kegiatan dalam melakukan transaksi yaitu
dengan menggunakan mobile banking. Mobile Banking adalah jenis fasilitas
layanan untuk melakukan transkasi melalui smartphone. Tujuan dari
penelitian ini untuk mengetahui pengaruh literasi keuangan, literasi digital
dan kemudahan penggunaan berpengaruh terhadap penggunaan mobile
banking BCA, BNI, BRI. Jenis penelitian adalah penelitian kuantitatif
deskriptif. Populasi penelitian yaitu mahasiswa Pendidikan Akuntansi
Universitas Negeri Surabaya. Sampel penelitian menggunaan purpose
sampel dengan kriteria mahasiswa aktif dan memiliki salah satu jenis mobile
banking BCA, BNI dan BRI. Pengumpulan data menggunakan tes dan
kuesioner di googleform dengan teknik analisis linear berganda. Hasil
penelitian ini menunjukkan bahwa (1) Literasi Keuangan secara parsial tidak
berpengaruh signifikan pada penggunaan mobile banking. (2) Literasi
Digital secara parsial tidak berpengaruh signifikan pada penggunaan mobile
banking. (3) Kemudahan Penggunaan secara parsial berpengaruh signifikan
pada penggunaan mobile banking. dan (4) Literasi Keuangan, Literasi
Digital dan Kemudahan Penggunaan secara simultan berpengaruh signifikan
pada penggunaan mobile banking.

Fakultas Ekonomika dan Bisnis Universitas Negeri Surabaya, Jawa Timur, Indonesia² 


\section{PENDAHULUAN}

Pada era masa globalisasi sekarang, suatu teknologi informasi menjadi cukup dominan yang sulit untuk dipisahkan dalam sektor kehidupan. Jumlah pengguna smartphone versi android dan ios semakin meningkat pesat yang diiringi pula dengan tingginya jumlah pengguna internet di dunia. Hasil survei Asosiasi Penyelenggara Jasa Internet Indonesia (APJII) periode 2020 total keseluruhan penggunaan internet di Indonesia mencapai 196,7 juta jiwa (APJII, 2020). Dengan adanya teknologi, kemudahan di berbagai sektor kehidupan termasuk dunia pembisnis. Para pelaku bisnis dituntut menciptakan hal baru dalam strategi persaingan pasar, setiap perusahaan berlomba untuk menciptakan produk dengan kualitas yang ekonomis, efektif, cepat, tepat dan aman untuk memenuhi kebutuhan konsumen pada masa sekarang maupun di masa depan.

Perkembangan bisnis financial technology (fintech) ikut berpengaruh salah satunya dalam sektor keuangan digital yang telah membuat sistem pembayaran dari tunai mulai beralih menjadi pembayaran secara non tunai yang lebih praktis, efektif, efisien dan simple. Hal ini dapat dilihat di berbagai jenis aplikasi yang ada di mobile atau telepon seluler. Kemudahan ini mendukung suatu aktivitas termasuk dalam melakukan transaksi. Alat transaksi yang dihasilkan pada era digital masa sekarang yaitu uang digital sesuai dengan Peraturan Bank Indonesia No. 11/12/PBI/2009 dan No. 16/8/PBI/2014 tentang pengurangan peredaran uang tunai sebagai bentuk dukungan terhadap program Bank Indonesia. Menurut Bank Indonesia (Bank Indonesia, 2020a) uang elektronik merupakan alat transaksi yang berbentuk elektronik yang tersimpan dalam perangkat elektronik yang digunakan dalam kegiatan transaksi. Uang elektronik menjadi bentuk pembayaran alternatif untuk memudahkan para pengguna untuk melakukan transaksi dengan cepat. Berikut merupakan tabel yang menunjukkan peningkatan jumlah uang digital di Indonesia pada tahun 2015-2020 menurut Bank Indonesia:

Tabel 1.

Jumlah Peredaran dan Transaksi Uang Elektronik di Indonesia 2015-2020

\begin{tabular}{ccccc}
\hline No & Tahun & Bulan & $\begin{array}{c}\text { Jumlah Peredaran } \\
\text { Uang Elektronik }\end{array}$ & $\begin{array}{c}\text { Volume Transaksi } \\
\text { Uang Elektronik }\end{array}$ \\
\hline 1. & 2015 & Desember & 34.314 .795 & 41.606 .578 \\
2. & 2016 & Desember & 51.204 .580 & 79.228 .422 \\
3. & 2017 & Desember & 90.003 .848 & 163.301 .280 \\
4. & 2018 & Desember & 167.205 .578 & 310.719 .605 \\
5. & 2019 & Desember & 292.299 .320 & 406.322 .079 \\
6. & 2020 & November & 420.412 .942 & 515.195 .069 \\
\hline
\end{tabular}

Sumber: (Bank Indonesia, 2020c, 2020d )

Berdasarkan data terbaru dari Bank Indonesia (BI), rata-rata nilai transaksi uang elektronik di Indonesia selama periode Januari-Juli 2020 meningkat menjadi 59\% atau 16,7 triliun dibandingkan dengan rata-rata transaksi pada periode tahun lalu denegan peredaran yang sama sebesar 9,9 triliun. Nilai transaksi tertinggi terjadi pada bulan April 2020 sebesar 17,5 triliun (Bank Indonesia, 2020b).

Pemanfaatan teknologi dalam dunia perbankan mulai menciptakan sistem aplikasi yang digunakan untuk membantu menjalanan operasional layanan sehari-hari. Diterapkannya teknologi informasi tersebut diharapkan mampu memberikan inovasi baru serta keunggulan-keunggulan komparatif dalam dunia perbankan yang memiliki tujuan untuk membantu pemutaran dana milik masyarakat dan menciptakan layanan bidang perbankan yang lebih inovatif serta kelembagaan keuangan negara sesuai dengan perkembangan zaman. Tidak hanya itu, slogan dalam pelayanan yang aman, terpercaya dan memberikan sesuai dengan kebutuhan msyarakat di masa sekarang yang mulai 
berkembang sejalan dengan teknologi informasi yang tren saat ini. Salah satu bentuk layanannya merupakan mobile banking.

Mobile banking adalah salah satu layanan atau fasilitas yang ditawarkan oleh pihak bank dengan tujuan untuk memenuhi kebutuhan nasabah dalam melakukan transaksi yang lebih memudahkan melalui smartphone dengan cara megunduh dan mengintalnya (Otoritas Jasa Keuangan, 2015). Dengan adanya layanan mobile banking akan membantu dan memudahkan nasabah, bank dan juga otoritas. Dari pihak nasabah, mobile banking mempermudah melakukan transaksi, cukup melalui smartphone yang telah terhubung dengan internet maka layanan akan dapat diakses selama 24 jam dengan begitu nasabah tidak perlu lagi datang dan mengantri di kantor untuk memperoleh informasi atau melakukan transaksi. Hal ini akan membuat penghematan waktu, biaya dan tempat. Segi pihak bank, mobile banking mampu menekan biaya operasional kantor jika dibandingkan dengan melakukan pelayanan secara langsung dengan nasabah dan peningkatan pendapatan berbasis komisi (fee based income) dan segi pihak otoritas mewujudkan transaksi menggunakan uang elektronik sesuai dengan gaya hidup masyarakat masa sekarang atau disebut dengan less cash societyi. Hal ini akan menyebabkan perputaran aktivitas perekonomian yang cepat dan stabilitas sistem keuangan (Otoritas Jasa Keuangan, 2015).

Metode transaksi secara online kini telah hidup secara perdampingan dengan kehidupan masyarakat masa sekarang. Penggunaan dompet digital mampu menaik para nasabah untuk menggunakannya setiap harinya. Kondisi saat ini tercermin dalam hasil riset Katadata Insight Center (KIC) tahun 2020.

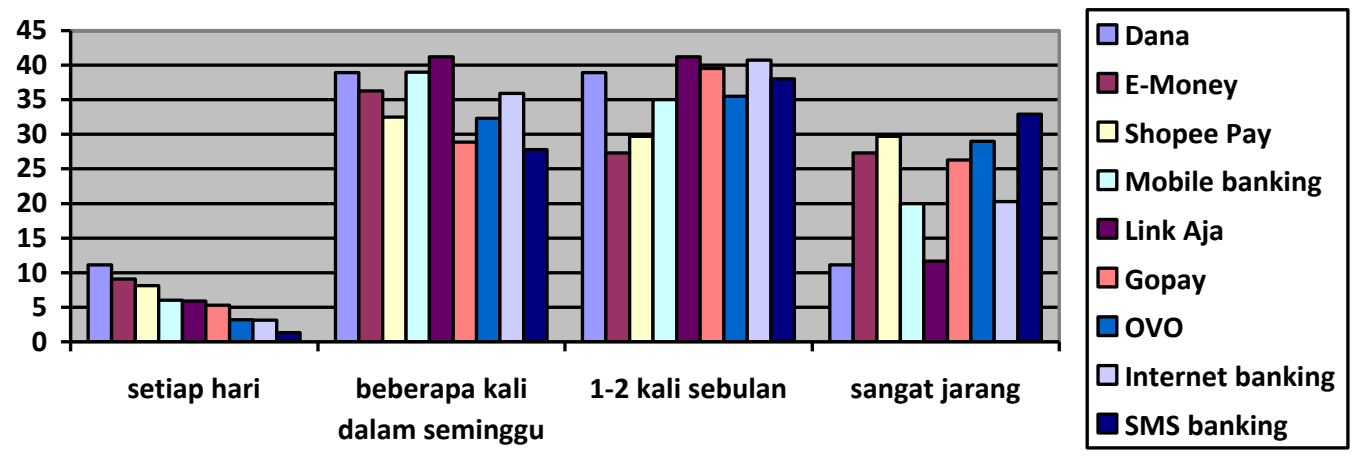

Sumber: Diolah Peneliti, 2021

\section{Gambar 1. \\ Frekuensi Penggunaan Layanan Perbankan Digital}

Menurut data survey Katadata Insight Center (KIC) tahun 2020 menyatakan bahwa mobile banking menduduki peringkat empat dengan hasil survey nasabah mengakses setiap hari sebanyak $6 \%$, beberapa kali dalam seminggu sebanyak 39\%, satu hingga 2 kali dalam sebulan sebanyak $35 \%$ dan nasabah yang mengakses sangat jarang sebanyak 20\% (Yosepha Pusparisa, 2020) dan didukung dengan penelitian (Fadlan \& Dewantara, 2018) yang menyatakan persentase penguna SMS/Mobile Banking pada tahun 2015 pengguna bank mandiri yang menggunakan mobile banking mencapai 6,6 juta, pengguna mobile banking BCA mencapai 5,2 juta, pengguna mobile banking BNI mencapai 3,25 juta dan pengguna mobile banking BRI mencapai 8,8 juta. Dalam segi transaksi mobile banking menjadi saluran perbankan yang cukup populer yang digunakan pada masa saat ini. Dengan fasilitas mobile banking yang diberikan bank kepada nasabahnya, setiap orang yang memiliki ponsel pintar atau smarphone akan lebih mudah untuk melakukan transaksi dimanapun dan kapanpun selama ponsel

Pengaruh Literasi Keuangan, Literasi Digital, Dan Kemudahan Penggunaan Terhadap Pelanggan Mobile Banking BCA, BNI, BRI 
pintar yang digunakan tersambung dengan internet. Manfaat lain tentunya akan dapat memanace waktu terutama dalam kehidupan sehari-hari seorang pembisnis tidak memiliki waktu yang cukup lama untuk melakukan transaksi maka cukup melalui ponsel genggamnya.

Seiring berkembangan teknologi, bank semakin maju untuk memanjakan nasabahnya salah satunya dengan menciptakan aplikasi Mobile Banking (M-Banking) untuk meyediakan alternatif layanan perbankan selain datang ke kantor cabang dan ATM dalam memenuhi kebutuhan masyarakat untuk melakukan transaksi perbankan. Menurut Bank Indonesia (BI) dalam penelitian Hadi \& Novi (2015) Mobile Banking (M-banking) adalah suatu layanan untuk melakukan sebuah transaksi keuangan dengan bantuan perangkat mobile yang telah terhubung dengan intenet dan sumber dana berasal dari tabungan nasabah bank yang bersangkutan. Penawaran layanan mobile banking ( $M$ Banking) kepada para nasabah bertujuan untuk mendukung kelancaran aktivitas dan kemudahan dalam melakukan transaksi. Layanan yang berikan bank bersifat personal, dapat menyesuaikan dengan karakteristik nasabahnya. Pada masa sekarang, mobile banking merupakan financial service provider $(F S P)$ yang artinya revolusi langkah awal bank. Sebagai FSP, bank berfungsi memanajemen keuangan para nasabahnya termasuk dalam hal pembayaran tagihan listrik, asurasi hingga perencanaan dana pensiun masa tua. Hal tersebut membuat fungsi dari suatu bank bukan sekedar tempat penyimpanan uang saja ataupun tempat penyaluran dana masyarakat. Menurut pendapat Lovelock \& Gummesson (2004) kualitas layanan mobile banking (m-banking) dibagi menjadi empat bagian yaitu pertama, speed adalah suatu kecepatan serta kemudahan untuk melakukan pengoperasian layanan mobile banking. Kedua, security adalah jaminan kerahasiaan oleh bank dalam melakukan layanan mobile banking. Ketiga, accuracy adalah suatu ketepatan dan keakuratan dalam memberikan informasi melalui mobile banking. Dan terakhir trust adalah kepercayaan nasabah terhadap bank dimana dapat menjalankan operasi layanan mobile banking.

Menurut Bank Sentral (2021), mobile banking tak ada berbeda pada SMS banking yang sama-sama dijalankan lewat smartphone. Pembeda hanya bila SMS banking digunakan metode SMS yang menggunakan pulsa sedangkan mobile banking digunakan melalui aplikasi yang harus diinstal pada smartphone dan dijalankan menggunakan internet. Berikut ini beberapa kelebihan pada mobile banking: (1) Layanan dapat akses 24 jam, pengguna mobile banking dapat mengakses 24 jam dalam melakukan transaksi kapan saja, dimana saja bahkan tengah malam. (2) Bisa menyimpan data transfer, penyediaan fitur menyimpan nomor rekening tujuan untuk memudahkan pengguna melakukan transaksi ulang dengan rekening yang sama. (3) Mudah digunakan, mobile banking didesain sederhana untuk memudahkan nasabah dengan sistem yang mudah diatur dengan fitur mudah untuk dipahami dan rinci. (4) Dapat mengetahui informasi produk terbaru pada bank terkait. (5) Transaksi lebih aman, aplikasi mobile banking menggunakan penerapan sistem kode akses untuk masuk pada akun rekening dan memasukkan PIN untuk melakukan transaksi. Kelemahan dari penggunaan mobile banking merupakan terdapat beberapa bank yang tidak bisa melakukan tarik tunai secara langsung dan mewajibkan memasukkan PIN yang telah diverifikasi melalui ke nomor hp yang terdaftar. Menurut Bank Sentral (2021), kelemahan lain dari penggunaan mobile banking yang akan kali terjadi pada pengguna yaitu berupa ketersediaan jaringan seluler operator. Dimana untuk mengakses mobile banking harus tersedianya internet yang ada di smartphone pengguna. Indikator dalam variabel penggunaan mobile banking menurut menurut (Afifah, 2017) (a) Pemakaian nyata (actual usage), (b) Frekuensi penggunaan, dan (c) Kepuasan penggunaan.

Perkembangan dimana konsep literasi tidak identik dengan kemelekan huruf, namun juga terhadap suatu teknologi dan bidang keuangan. Literasi keuangan berkaitan dengan keahlian seseorang dalam mengelola keuangan. Seseorang yang memiliki literasi keuangan yang cukup tinggi akan menimbulkan keahlian dan kemampuan pada diri seesorang tersebut untuk dapat memanfaatkan

Pengaruh Literasi Keuangan, Literasi Digital, Dan Kemudahan Penggunaan Terhadap Pelanggan Mobile Banking BCA, BNI, BRI 
sumber daya yang ada. Menurut pendapat Lusardi \& Mitchell (2014) menyatakan literasi keuangan merupakan kemampuan seseorang untuk melakukan proses informasi ekonomi untuk membuat suatu keputusan tentang rencana keuangan, akumulasi kekayaan, hutang dan pensiun. Chen dan Volpe, 1998 dalam (Yushita, 2017) juga mendefinisikan bahwa pengetahuan atas pengelolaan keuangan dalam rangka pengambilan keputusan yang terkait dengan keuangan. Indikator dalam penelitian ini menurut Chen dan Volpe, 1998 dalam (Yushita, 2017) terdiri atas Pertama, pengetahuan umum keuangan pribadi; Kedua, Tabungan dan Pinjaman; Ketiga, asuransi; dan terakhir Investasi. Penelitian sebelumnya yang telah dilakukan oleh (Ramdani, 2020) dan (Awalina, 2018) menunjukkan bahwa literasi keuangan mempunyai pengaruh yang begitu positif, berbeda dengan penelitian yang dilakukan oleh (Dwiningsih, 2020) yang menghasilkan literasi keuangan secara langsung tidak berpengaruh. Berdasarkan perbedaan pendapat hasil penelitian-penelitian, maka penelitian ini dilakukan untuk menguji pengaruh literasi keuangan terhadap penggunaan mobile banking. Hipotesis yang diciptakan penelitian ini yaitu : H1: Literasi keuangan secara parsial berpengaruh terhadap penggunaan mobile banking.

Pengetahuan digital seseorang tetap harus lebih diasah, terutama dalam hal menerima atau menolak, mengevaluasi, menemukan, suatu informasi yang didapat. Menurut Mohammadyari \& Singh (2015) literasi digital adalah kemampuan seseorang dalam pemahaman, penganalisisan, penilaian, pengaturan serta pengevaluasian suatu informasi yang didapat dengan bantuan alat bantu teknologi digital. Dengan memiliki literasi digital, seseorang dapat mengetahui suatu teknologi dan memahami bagaimana cara mengoperasikannya serta sadar yang akan ditimbulkan. Tetapi dengan kemampuan literasi digital komunikasi dengan orang lain akan terasa lebih mudah, lebih efektif dan peningkatan produktivitas terutama pada seseorang yang memiliki tingkat kemampuan dan keterampulan yang sama. Seseorang yang memiliki literasi digital yang tinggi akan dapat lebih memanfaatkan teknologi, menggunakan dan memahami konten digital secara benar dan tepat. Indikator penelitian ini dari variael literasi digital yang sesuai yaitu menurut (Gilster, 1997) yaitu : (a) Pencarian di internet; (b) panduan arah; (c) Evaluasi konten informasi; (d) Penyusunan pengetahuan. Berdasarkan penelitian yang telah dilakukan oleh (Dwiningsih, 2020) serta (Vebiana, 2018) yang membuktikan bahwa literasi digital berpengaruh positif dan meningkat kinerja perbankan, berbeda dengan penelitian (Susilawaty \& Nicola, 2020) yang menunjukkan bahwa layanan perbankan digital tidak berpengaruh positif signifikan. H2: Literasi digital secara parsial berpengaruh terhadap penggunaan mobile banking.

Theory of Reasoned Action yang diadaptasi dari teori TAM yang dikenalkan dengan Ajzen dan Fisbein pada tahun 1980 dan diusulkan oleh (Davis, 1989) yang mengungkapkan perceived usefulness (persepsi kemudahan) dan perceied ease of ue (persepsi kemudahan penggunaan) mempengaruhi attitude toward using terhadap penggunaan suatu teknologi. Menurut Davis (1989) dalam Ramadhan \& Herianingrum (2017) Technology Acceptance Model (TAM) merupakan model untuk melihat diterima atau tidaknya penggunaan teknologi komputer, yang mana penggunaannya ditentukan oleh minat perilaku. Minat perilaku ditentukan oleh sikap terhadap perilaku masing-masing individu dan persepsi terhadap kemudahan penggunaan. Model TAM dikembangkan untuk menjelaskan perilaku penggunaan komputer dengan landasan atas kepercayaan, sikap, keinginan, dan hubungan perilaku sikap. Persepsi terhadap kemudahan dalam penggunaan suatu teknologi akan dapat berpengaruh terhadap sikap pribadi seseorang dalam menggunakan teknologi itu sendiri yang akan menentukan seorang individu tertarik dalam menggunakan teknologi tersebut. Dengan demikian, selama individu merasa suatu teknolgi akan memudahkan dalam meneyelsaikan tugas-tugasnya, ia akan tertarik untuk menggunakannya.

Kemudahan penggunaan komponen utama dari teori TAM. Kemudahan penggunaan merupakan dimana seseorang yakin bahwa dalam menggunakan atau menjalankan suatu sistem 
tertentu akan jauh lebih mudah dan saat melakukannya tidak perlunya usaha yang keras (Huan et al., 1996). Menurut Cudjoe, Anim, \& Tetteh Nyanyofio (2015) seseorang menganggap suatu sistem teknologi yang mudah untuk digunakan dalam melakukan pengoperasian atau menjalan sistem tersebut bebas dari penggunaan fisik dan mental seseorang, maka orang tersebut akan menggunakannya secara terus-menerus. Berdasarkan penjabatan di atas, maka peneliti menggunakan indikator menurut (Venkatesh \& Davis, 2000) yaitu (a) mudah dipelajari (b) efisien waktu (c) fleksibel, dan (d) mudah digunakan. Penelitian yang dilakukan oleh (Dewi, Sabri, \& Winata, 2018; Kristianti \& Pambudi, 2017; Ramadhan \& Herianingrum, 2017; Sigar, 2016) membuktikan bahwa kemudahan penggunaan memiliki pengaruh positif yang signifikan terhadap penggunaan mobile banking, berbeda dengan penelitian yang dilakukan oleh (Awalina, 2018) membuktikan bahwa persepsi kemudahan tidak memiliki pengaruh positif signifikan. Berdasarkan landasan teori bahwa kemudahan penggunaan diharapkan dapat memiliki pengaruh terhadap penggunaan mobile banking, maka peneliti mengajukan hipotesis sebagai berikut: H3: Kemudahan penggunaan secara parsial berpengaruh terhadap penggunaan mobile banking.

Suatu produk yang di ciptakan dalam bentuk aplikasi terdapat kemudahan seseorang dalam penggunaan. Banyak masyarakat memutuskan untuk lebih memilih hal yang simpel dan praktis dalam melakukan sesuatu. Dengan kemudahan tersebut maka seseorang berpikir bagaimana cara untuk lebih dapat meningkatkan pengetahuan dan pengelolaan agar dapat mengikuti gaya hidup dan tren pada saat ini. Dengan kemudahan yang didapatkan dalam penggunaan mobile banking, maka membuat seseorang juga harus pandai dalam pengelolaan keuangannya dan pengetahuan tentang digital, dengan begitu dalam menjalankan suatu sistem dengan inovasi terbaru akan membuat seseorang mengalami kemudahan. H4: Literasi keuangan, literasi digital dan kemudahan penggunaa secara simultan berpengaruh terhadap penggunaan mobile banking.

Dari uraian masalah, fenomena dan penjabaran teori maupun pendapat. Tujuan atas adanya penelitian ini ialah untuk menganalisis adanya pengaruh dari variabel independen yaitu Literasi Keuangan $\left(\mathrm{X}_{1}\right)$; Literasi Digital $\left(\mathrm{X}_{2}\right)$ dan Kemudahan Penggunaan $\left(\mathrm{X}_{3}\right)$ secara simultan dan parsial terhadap variabel dependen yaitu Penggunaan Mobile Banking (Y) BCA, BNI, BRI

\section{METODE PENELITIAN}

Dalam penelitian ini menggunakan jenis penelitian kuantitatif yaitu penelitian yang berlandasan filsafat positivisme yang berupa angka untuk menguji hipotesis (Sugiyono, 2017). Populasi penelitian adalah seluruh mahasiswa Prodi Pendidikan Akuntansi Fakultas Ekonomi dan Bisnis Universitas Negeri Surabaya angkatan 2017-2019 dengan jumlah 220 mahasiswa. Digunkan teknik purposive sampling dalam penentuan sampel dengan kriteria mahasiswa yang aktif di perkuliahan dan mahasiswa yang telah memiliki salah satu dari mobile banking BCA, BNI ataupun BRI berjumlah 72 orang.

Teknik pengambilan data dengan menggunakan tes dan kuesioner. Dalam hal ini tes dilakukan untuk mengukur besar pengaruh literasi keuangan dan literasi digital, sedangkan kuesioner digunakan untuk mengukur besar pengaruh kemudahan penggunaan dan penggunaan mobile banking. Instrumen penelitian yakti terdiri dari 20 pertanyaan pada variabel literasi keuangan, 20 pertanyaan pada variabel literasi digital, 10 pernyataan pada variabel kemudahan penggunaan dan 10 pernyataan pada variabel penggunaan mobile banking. Skala yang digunakan dalam penelitian ini adalah kala guttman dan skala liker. Skala guttman digunakan pada variabel literasi keuangan dan variabel literasi digital dengan skor yaitu $1=$ benar dan $0=$ salah. Untuk penilaian pada variabel independen kemudahan penggunaan dan penggunaan mobile banking menggunakan skala likert menurut

Pengaruh Literasi Keuangan, Literasi Digital, Dan Kemudahan Penggunaan Terhadap Pelanggan Mobile Banking BCA, BNI, BRI 
(Sugiyono, 2017) terdapat skor jawaban: Sangat setuju; Setuju; Netral/Ragu-Ragu; Tidak setuju; dan Sangat tidak setuju. Adapun teknik analisis data yang digunakan pada penelitian ini yaitu analisis regresi linear berganda dengan bantuan program SPSS 25. Adapun penggunaan tekniknya dalam pengujian dan penganalisisan data memakai Uji validitas, Uji Reabilitas, Uji Asumsi Klasik dan Analisis data. Dari hasil penyebaran tes dan kuesioner yang telah diolah maka diperoleh hasil dengan sampel yang ditentukan.

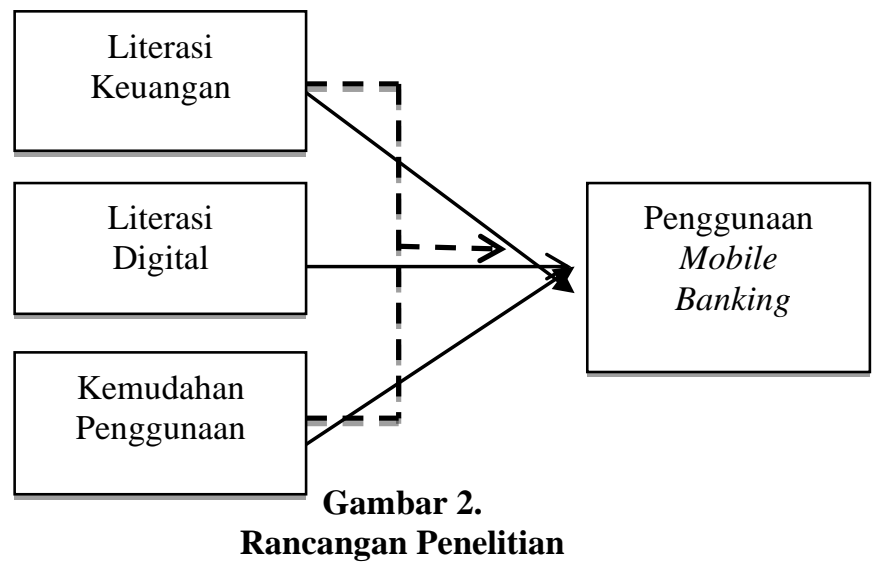

\section{HASIL DAN PEMBAHASAN}

Hasil penyebaran tes dan kuesioner, ada 72 responden yang telah mengisi dan memenuhi kriteria. Data yang diperoleh berupa kategori responden dan analisis data terkait pengaruh literasi keuangan, literasi digital dan kemudahan penggunaan terhaap penggunaan mobile banking.

Tabel 2.

Kategori Responden

\begin{tabular}{ccc}
\hline \multicolumn{1}{c}{ Kategori } & Jumlah & Presentase \\
\hline Jenis Kelamin & & \\
Laki-Laki & 10 anak & $13,7 \%$ \\
Perempuan & 62 anak & $86,3 \%$ \\
Penggunaan Mobile Bankig & & \\
BCA & 27 anak & $37,5 \%$ \\
BNI & 17 anak & $23,6 \%$ \\
BRI & 28 anak & $38,9 \%$ \\
\hline
\end{tabular}

Sumber : Diolah peneliti, 2021

Berdasarkan tabel 2 menunjukkan bahwa karakteristik pertama responden didominasi oleh perempuan degan total presentase $86,3 \%$ dibandingkan dengan laki-laki hanya $13,7 \%$. Karakteristik kedua adanya mahasiswa yang memiliki mobile banking terbanyak yaitu pengguna mobile banking BRI dengan presentasi 38,9\%, peringkat kedua BCA sebesar 37,5\% dan terakhir pengguna mobile banking BNI sebesar 23,6\%. Hal ini dapat menunjukkan bahwa perempuan lebih dominan pada menggunakan mobile banking untuk melakukan transaksi sehari-hari karena banyak dari e-commers

Pengaruh Literasi Keuangan, Literasi Digital, Dan Kemudahan Penggunaan Terhadap Pelanggan Mobile Banking BCA, BNI, BRI 
dan pusat pembelanjaan mulai beralih menggunakan pembayaran non tunai. Banyak kemudahan yang didapat membuat banyak masyarakat terutama mahasiswa yang mulai menggunakannya.

Model analisis yang digunakan dalam penelitian ini menggunakan analisis regresi linear berganda yang digunakan untuk menentukan hipotesis yang telah dirumuskan diterima ataupun ditolak. Hasil analisis regresi berganda untuk mengetahui pengaruh dari Literasi Keuangan, Literasi Digital dan Kemudahan Penggunaan terhadap Penggunaan Mobile Banking. Berdasarkan hasil uji analisis data menunjukkan bahwa sebagai berikut:

Tabel 3.

Hasil Regresi Linear Berganda

\begin{tabular}{lcc}
\hline \multicolumn{1}{c}{ Model } & Koefisien Regresi & Std. Error \\
\hline Constant & 1,072 & 4,695 \\
Literasi Keuangan $\left(\mathrm{X}_{1}\right)$ & $-2,44$ & 0,154 \\
Literasi Digital $\left(\mathrm{X}_{2}\right)$ & 0,110 & 0,193 \\
Kemudahan Penggunaan $\left(\mathrm{X}_{3}\right)$ & 0,929 & 0,0925 \\
\hline
\end{tabular}

Sumber : diolah peneliti, 2021

Berdasarkan hasil data pada Tabel 3, maka didapat persamaan analisis linear berganda dengan rumus sebagai berikut:

$$
\mathrm{Y}=1,072+-2,44 \mathrm{X}_{1}+0,110 \mathrm{X}_{2}+0,929 \mathrm{X}_{3}+\mathrm{e}
$$

Keterangan:

$\mathrm{Y} \quad=$ Penggunaan Mobile Banking BCA, BNI, BRI

$\mathrm{X} 1=$ Literasi Keuangan

$\mathrm{X} 2=$ Literasi Digital

X3 = Kemudahan Penggunaan

Dapat dilihat hasil analisis regresi berganda memperlihatkan jumlah nilai konstanta yang diperoleh adalah 1,072 menunjukkan adanya pengaruh positif terhadap variabel independen (Literasi Keuangan, Literasi Digital dan Kemudahan Penggunaan). Bila variabel independen tinggi ataupun berpengaruh dalam satusatuan, maka variabel dependen (Penggunaan Mobile Banking) akan tinggi pula atau terpenuhi. Nilai koefisien regresi pada variabel Literasi Keuangan $\left(\mathrm{X}_{1}\right)$ sebesar -2,44 memiki nilai negatif yang berarti bahwa jika variabel Literasi keuangan yang semakin rendah maka penggunaan mobile banking semakin rendah. Nilai koefisien regresi pada variabel Literasi Digital $\left(\mathrm{X}_{2}\right)$ besarnya 0,110 memiliki nilai positif yang artinya jika varabel Literasi Digital makin tinggi maka penggunaan mobile banking akan semakin meningkat atau tinggi. Nilai koefisien regresi pada variabel Kemuahan Penggunaan $\left(\mathrm{X}_{3}\right)$ sebesar 0,929 dan memiliki nilai positif bermakna jika varial kemudahan penggunaan makin tinggi maka penggunaan mobile banking akan semakin meningkat.

Dalam model regresi dikatakan model yang baik bila mana model tersebut bebas dari asumsi klasik statistk. Uji asumsi klasik dilakukan untuk menguji kelayakan model seperti uji multikolinearitas, uji normalitas dan uji heteroskedastisitas. Uji normalitas adalah uji statistik yang digunakan untuk menguji apakah suatu residual model regresi berdistribusi normal ataupun tidak, dengan menggunakan Kolmogrov-Smirov dan jika koefisien Asymp. Sig (2-tailed) > level of significant (lebih besar dari 0,05), maka dapat dikatakan brdistribusi normal. 
Tabel 4

Hasil Uji Normalitas

Unstandardized Residual

Asymp. Sig. (2-tailed)

0,072

Sumber: diolah peneliti, 2021

Berdasarkan tabel 4 nilai Kolmogrov-Smirov dengan nilai sig dari Unstandardized Residual $0,072>0,05$ sehingga nilai residualnya dinyatakan memiliki distribusi normal datanya. Uji kedua yaitu uji multikolinieritas yang digunakan untuk menguji model regresi berganda yang ditemukan dengan adanya korelasi antar variabel bebas dari adanya gejala multikolineritas yang dapat dilihat dari nilai tolerance dan nilai variance inflation factor (VIF). Hasil analisis uji multikolinearitas disajika pada tabel 5.

Tabel 5.

Hasil Uji Multikolinieritas

\begin{tabular}{lcc}
\hline \multicolumn{1}{c}{ Model } & Tolerance & VIF \\
\hline Literasi Keuangan $\left(\mathrm{X}_{1}\right)$ & 0,750 & 1.334 \\
Literasi Digital $\left(\mathrm{X}_{2}\right)$ & 0,760 & 1,316 \\
Kemudahan Penggunaan $\left(\mathrm{X}_{3}\right)$ & 0,984 & 1,016 \\
\hline
\end{tabular}

Sumber: diolah peneliti, 2021

Berdasarkan tabel 5. pada variabel Literasi Keuangan $\left(\mathrm{X}_{1}\right)$, Literasi Digital $\left(\mathrm{X}_{2}\right)$, Kemudahan Penggunaan $\left(\mathrm{X}_{3}\right)$ dan Penggunaan Mobile Banking (Y) mempunyai nilai $>0,01$ dan untuk nilai VIF pada variabel bebas Literasi Keuangan $\left(\mathrm{X}_{1}\right)$ sebesar 1,334<10, varibel Literasi Digital $\left(\mathrm{X}_{2}\right)$ sebesar $1,316<10$ dan terakhir pada variabel Kemudahan Penggunaan $\left(\mathrm{X}_{3}\right)$ memperoleh nilai VIF sebesar 1,016 atau berarti $<10$ yang menyatakan yakni tidak adanya gejala multikolinieritas.

Uji ketiga yaitu uji heteroskedasitas bertujuan untuk menguji dalam model regresi adanya ketidaksamaan antara variance dan residual satu pengamatan dengan pengamatan yang lain. Apabila tingkat signifikan masing-masing pada variabel bebas lebih besar dari 0,05, maka pada model regresi todak ditemukan adanya gejala heteroskedasitas. Hasil heteroskedasitas yang disajikan pada Tabel 6 .

Tabel 6.

Hasil Uji Heteroskedasitas

\begin{tabular}{lcl}
\hline \multicolumn{1}{c}{ Model } & $\mathrm{T}$ & Sig. \\
\hline Literasi Keuangan $\left(\mathrm{X}_{1}\right)$ & $-1,585$ & 0,118 \\
Literasi Digital $\left(\mathrm{X}_{2}\right)$ & 0,571 & 0,570 \\
Kemudahan Penggunaan $\left(\mathrm{X}_{3}\right)$ & 9,748 & 0,000 \\
\hline
\end{tabular}

Sumber: diolah peneliti, 2021 
Berdasarkan tabel 6. uji heterosdedasitas diperoleh nilai Sig dengan variabel Literasi Keuangan $\left(\mathrm{X}_{1}\right)$ sebesar 0,118>0,05 dan variabel Literasi Digital $\left(\mathrm{X}_{2}\right)$ sebesar 0,570>0,05 menyatakan bahwa variabel Literasi Keuangan dan Literasi Digital tak adanya gejala heteroskedasitas. Berbeda dengan variabel Kemudahan Penggunaan $\left(\mathrm{X}_{3}\right)$ sebesar $0,000<0,05$ yang artinya bahwa pada vaiabel tersebut adanya gejala heteroskedasitas.

Pada uji $\left(\mathrm{R}^{2}\right)$ atau $\mathrm{R}$ Square, yang menjelaskan bahwa ukuran kesesuaian regresi yaitu pada variabel independen yang mampu menjelaskan variabel dependen. Berdasarkan hasil uji koefisien determinan $\left(\mathrm{R}^{2}\right)$ sebagai berikut:

Tabel 7.

Hasil Uji Analisis Determinan

\begin{tabular}{ccc}
\hline $\mathrm{R}$ & $\mathrm{R}$ Square & Adjusted $R$ squeres \\
\hline 0,764 & 0,584 & 0,565 \\
\hline
\end{tabular}

Sumber: diolah peneliti, 2021

Berdasarkan pada tabel 4 nilai koefisien determinasinya atau Adjusted R Square pada uji determinan sebesar 0,584 bermakna kontribusi dari variabel bebasnya yaitu Literasi Keuangan, Literasi Digital dan Kemudahan Penggunaan memiliki pengaruh pada Penggunaan Mobile Banking sebesar 58,4\% sedangkan $41,6 \%$ dipengaruhi oleh faktor lain.

Tabel 8.

Hasil Uji Parsial (Uji t)

\begin{tabular}{lcl}
\hline \multicolumn{1}{c}{ Variabel } & $\mathrm{T}$ & Sig. \\
\hline Constant & 0,228 & 0,820 \\
Literasi Keuangan $\left(\mathrm{X}_{1}\right)$ & $-1,585$ & 0,118 \\
Literasi Digital $\left(\mathrm{X}_{2}\right)$ & 0,571 & 0,570 \\
Kemudahan Penggunaan $\left(\mathrm{X}_{3}\right)$ & 9,748 & 0,000
\end{tabular}

Sumber: diolah peneliti, 2021

Berdasarkan hasil data uji parsial (uji t) pada variabel literasi keuangan (X1) sebesar 1,585<1,667 dan mendapatkan nilai signifikainya sebesar 0,118>0,05 maka variabel literasi keuangan tidak berpengaruh negatif signifikan terhadap penggunaan mobile banking. Hal ini memungkinkan kurangnya edukasi dalam pelaksanaan peningkatan pemahaman keuangan di masyarakat. Dengan diiringi pesatnya perkonomian dan kemajuan teknologi pada masa sekarang juga perlunya pengetahuan keuangan yang lebih dalam. Dalam hal ini literasi keuangan sangat berpengaruh pula dengan suatu kesejahteraan seseorang. Pengetahuan dan pengeloaan keuangan sangat penting untuk kehidupan sehari-harinya. Dengan didukung kemudahan dalam pengelolaan keuangan, maka dapat meningkatkan pengelolaan yang baik untuk kesejahteraan individual. Tetapi tidak dengan kenyataan, banyak masyarakat yang lebih memudahkan keuangan tanpa mengontrol pengeluran keuangan dan beraki seorang individu tidak dapat mengendalikan keuangannya.

Hasil dari penelitian ini sejalan dengan penelitian yang telah dilakukan oleh peneliti sebelumnya yaitu (Dwiningsih, 2020) yang menyatakan bahwasanya pada variabel literasi keuangan secara langsung tidak berpengaruh pada partisipasi perbankan. Hal ini disebabkan banyak masyarakat terutama mahasiswa yang minim akan pengetahuan tentang keuangan. menganggap dengan adanya kemudahan yang diberikan membuat rasa ingin melakukan transaksi semakin tinggi tanpa disadari 
lemahnya pengelolaan keuangan secara pribadi. Banyak mahasiswa yang mudah tergiur dengan keadaan yang membuat literasi keuangan yang kurang.

Menurut pada hasil dari uji parsial (uji t) pada variabel literasi digital (X2) sebesar $0,571<1,667$ dan mendapatkan nilai signifikasinya sebesar $0,570<0,05$ artinya variabel literasi digital tidak berpengaruh positif signfikan pada penggunaan mobile banking. Hasil dari penelitian ini sejalan pada penelitian sebelumnya yaitu (Susilawaty \& Nicola, 2020) variabel literasi digital yang membuktikan bahwa tidak adanya pengaruh positif signifikan terhadap digital banking. Semakin baik kualitas literasi digital seseorang akan mempermudah seseorang untuk menggali dan penggunaan informasi yang serba digital pada saat ini, tetapi berbeda dengan penelitian ini yang membuktikan dan menunjukkan bahwa banyak seseorang hanya ingin mencoba tanpa harus mempelajari informasi yang didapatnya. Banyak nasabah yang masih suka berinteraksi langsung di teller atau customer servis secara langsung.

Berdasarkan hasil uji parsial (uji t) pada variabel kemudahan penggunaan thitung >ttabel pada variabel kemudahan sebesar 9,748>1,667 dan mendapatkan nilai signifikasinya sebesar $0,000<0,05$ maka dinyatakan pengaruh positif signifikan terhadap penggunaan mobile bankng. Uji tersebut menunjukkan bahwa kemudahan penggunaan dalam mobile banking bersifat efektif, efisien dan aman untuk digunakan. Selain itu dari segi kemampuan melakukan transaksi mobile banking memudahkan penggunanya untuk melakukan pembayaran karena tidak perlu membawa uang tunai terlalu banyak. Dari segi kemudahan operasional, pengguna dapat mudah untuk melakukan pengoperasional tanpa belajar dengan waktu yang cukup lama. Dari segi efisien waktu, dengan mudah dan cepat melakukan pembayaran ataupun transaksi hanya melalui smarthone mereka. Khususnya untuk mahasiswa Universitas Negei Surabaya, mobile banking banyakmemberikan kemudahan pada kegiatan seharihari seperti mengecek transfer dari orang tua untuk anak perantauan. Pembelian pulsa, paket data. Pengisian saldo untuk melakukan belanja melalui ecommers karena memudahkan dan murah dibandingkan dengan membeliproduk secara offline.

Hasil penelitian ini didukung dengan teori Technology Acceptance Model (TAM) dari (Davis, 1989; Ramadhan \& Herianingrum, 2017) dimana seseorang mampu menerima persepsi terhadap kemudahan dalam penggunaan suatu teknologi. Penelitian ini juga selinear dengan penelitian sebelumnya yang dilakukan oleh (Dewi et al., 2018; Kristianti \& Pambudi, 2017; Ramadhan \& Herianingrum, 2017) yang mengatakan bahwa kemudahan penggunaan memiliki pengaruh positif signifikan terhadap penggunaan mobile banking dan juga pada penelitian (Sigar, 2016) yang membuktikan bahwa kemudahan penggunaan berpengaruh positif signifikan pada use electronic money.

Tabel 9.

Hasil Uji Simultan (Uji F)

\begin{tabular}{ccc}
\hline Model & F & Sig \\
\hline Regression & 31,765 & 0,000 \\
\hline
\end{tabular}

Sumber : diolah peneliti, 2021

Berdasarkan Uji Simultan (Uji F) terhadap Tabel 8 menunjukkan bahwa Fhitung pada Uji F sebesar 31,765 memiliki nilai besarnya lebih dari Ftabel dengan angka yaitu 3,13 dan nilai signifikannya sebesar 0,000 yang bernilai lebih kecil daripada 0,05 sehingga dapat ditarik kesimpulan bahwa $\mathrm{H}_{4}$ dapat diterima, berarti secara simultan untuk variabel Litrasi keuangan, Literasi Digital dan Kemudahan Penggunaan memiliki pengaruh terhadap Penggunaan Mobile Banking. Karena semua hal yang yang telah ditawarkan oleh bank dengan menciptakan Mobile Banking baik berupa kemudahan

Pengaruh Literasi Keuangan, Literasi Digital, Dan Kemudahan Penggunaan Terhadap Pelanggan Mobile Banking BCA, BNI, BRI 
penggunaan secara tidak langsung memunculkan rasa ingin menggunakan dari seorang konsumen. Perilaku tersebut dapat dilihat dari terlibatnya penggunaan Mobile Banking dalma kehidupan seharihari untuk melakukan transaksi, pembayaran dan lain sebagainya. Hal ini dapat dilihat pula dari hasil penelitian yang dilakukan menunjukkan bahwa mahasiswa Prodi Pendidikan Akuntansi Fakultas Ekonomi dan Bisnis Universitas Negeri Surabaya sebagian besar telah menginstal dan menggunakan mobile banking di ponsel pintarnya dalam menunjang kegiatan sehari-hari. Hasil penelitian ini didukung dengan penelitian sebelumnya yang dilakukan (Marisa, 2020) yang membuktikan bahwa literasi keuangan, promosi uang elektronik dan kemudahan penggunaan secara simultan berpengaruh yang signifikan pada keputusan penggunaan uang elektronik.

\section{SIMPULAN DAN SARAN}

Berdasarkan pada analisis hasil penelitian yang telah dilakukan, maka dapat disimpulkan bahwasannya banyak mahasiswa yang mulai beralih pembayaran menggunakan mobile banking. Selain itu, hasil penelitian ini menjelaskan bahwa literasi keuangan secara parsial tidak memiliki pengaruh signifikan terhadap penggunaan mobile banking. Begitu pula dengan liteasi digital secara parsial tidak memiliki pengaruh yang positif signifikan terhadap penggunaan mobile banking. Sedangkan kemudahan penggunaan secara parsial memiliki pengaruh positif signifikan terhadap penggunaan mobile banking. Dan untuk uji simultan mendapatkan hasil 31,765>3,13 memiliki nilai signifikan <0,05 yan artinya literasi keuangan, literasi digital dan kemudahan penggunaan secara simultan berpengaruh dan signifikan terhadap penggunaan mobile banking.

Dari penelitian yang telah disimpulkan dapat diberikan saran beberapa hal yaitu bagi mahasiswa perlu memperdalam ilmu tentang keuangan dan digital dari berbagai sumber sehingga dapat meningkatkan penggunaan teknologi yang sedang tren untuk saat ini dan untuk penelitian selanjutnya diharapkan dapat mengembangkan penelitian yang yang telah ada atau bisa menambah variabel bebas lainnya serta memperluas ruang lingkup penelitian untuk melihat faktor yang mempengaruhi.

\section{REFERENSI}

Afifah, R. (2017). Pengaruh Manfaat, Kemudahan, Kepercayaan Dan Ketersediaan Fitur Terhadap Penggunaan Mobile Banking Bank Syariah Mandiri. 1-182.

APJII. (2020). Laporan Survei Internet APJII 2019 - 2020. Asosiasi Penyelenggara Jasa Internet Indonesia, 2020, 1-146. Retrieved from https://apjii.or.id/survei

Awalina, M. (2018). Pengaruh Persepsi Kemanfaatan, Kemudahan Dan Literasi Keuangan Terhadap Minat Penggunaan Uang Elektronik Berbasis Server Di Kalangan Mahasiswa Dalam Perspektif Islam. Journal of Chemical Information and Modeling, 53(9), 1689-1699.

Bank Indonesia. (2020a). Apa itu Uang Elektronik. Retrieved January 1, 2020, from Bank Indonesia website: https://www.bi.go.id/id/edukasi/Pages/Apa-itu-Uang-Elektronik.aspx

Bank Indonesia. (2020b). Berapa Nilai Transaksi Uang Elektronik di Indonesia Selama Pandemi? Nilai Transaksi Uang Elektronik (Agustus 2019 - Juli 2020). Retrieved January 1, 2021, from databoks. website: https://databoks.katadata.co.id/datapublish/2020/09/28/berapa-nilai-transaksi-uang-elektronik-diindonesia-selama-pandemi

Bank Indonesia. (2020c). Statistik Sistem Pembayaran (SPP) Jumlah Uang Elektronik Beredar. Retrieved January 1, 2021, from Bank Indonesia website: https://www.bi.go.id/id/statistik/ekonomikeuangan/ssp/uang-elektronik-transaksi.aspx

Bank Indonesia. (2020d). Statistik Sistem Pembayaran (SPP) Transaksi Uang Elektronik. Retrieved January 1, 2021, from Bank Indonesia website: https://www.bi.go.id/id/statistik/ekonomi-keuangan/ssp/uangelektronik-transaksi.aspx

Bank Sentral. (2021). Kelebihan dan Kekurangan ATM, SMS Banking, Mobile Banking, dan Internet Banking. Pengaruh Literasi Keuangan, Literasi Digital, Dan Kemudahan Penggunaan Terhadap Pelanggan Mobile 
Retrieved November 7, 2020, from Bank Sentral website: https://banksentral.com/kelebihan-dankekurangan-atm-sms-banking-mobile-banking-dan-internet-banking/\#h-3-kelebihan-dan-kekuranganmobile-banking-m-banking

Cudjoe, A. G., Anim, P. A., \& Tetteh Nyanyofio, J. G. N. (2015). Determinants of Mobile Banking Adoption in the Ghanaian Banking Industry: A Case of Access Bank Ghana Limited. Journal of Computer and Communications, 03(02), 1-19. https://doi.org/10.4236/jcc.2015.32001

Davis, F. D. (1989). Perceived Usefulness, Perceived Ease Of Use, And User Acceptance Of Information Technology.

Dewi, S., Sabri, S., \& Winata, V. P. (2018). Analisis Kemudahan Penggunaan, Efisiensi dan Keamanan Terhadap Minat Nasabah Bertransaksi Menggunakan BSM Mobile Banking Pada Bank Syariah Mandiri Kantor Cabang Payakumbuh. EKONOMIKA SYARIAH: Journal of Economic Studies, 2(2), 203-234. https://doi.org/10.30983/es.v2i2.723

Dwiningsih, Y. W. (2020). Literasi Keuangan, Literasi Layanan Keuangan Digital Dan Partisipasi Perbankan Pada Siswa Sma Komplek Surabaya. Retrieved November 7, 2020, from http://repository.unair.ac.id/98269/

Fadlan, A., \& Dewantara, R. Y. (2018). Pengaruh Persepsi Kemudahan dan Persepsi Kegunaan Terhadap Penggunaan Mobile Banking (Studi Pada Mahasiswa Pengguna Mobile Banking Universitas Brawijaya). Jurnal Administrasi Bisnis (JAB), 62(1), 82-89. Retrieved from http://administrasibisnis.studentjournal.ub.ac.id/index.php/jab/article/viewFile/2652/3045

Hadi, S., \& Novi, N. (2015). Faktor-Faktor Yang Mempengaruhi Penggunaan Layanan Mobile Banking. Optimum: Jurnal Ekonomi Dan Pembangunan, 5(1), 55. https://doi.org/10.12928/optimum.v5i1.7840

Huan, S. D., Yau, J. C., Tomiak, E., Goel, R., Cripps, C., Gertler, S. Z., ... Stewart, D. J. (1996). Hydroxyurea Did Not Enhance the Clinical Response to Vinblastine in Patients with Anthracycline-Resistant Metastatic Breast Cancer. Tumori Journal, 82(6), 576-578. https://doi.org/10.1177/030089169608200612

Kristianti, M. L., \& Pambudi, R. (2017). Analisis Pengaruh Persepsi Kemudahan, Persepsi Kemanfaatan, Persepsi Tingkat Keamanan, Dan Fitur Layanan Terhadap Penggunaan Mobile Banking Pada Mahasiswa Di DKI Jakarta. Jurnal Akuntansi, 11(1), 50-67. https://doi.org/10.25170/jara.v11i1.52

Lovelock, C., \& Gummesson, E. (2004). Whither Services Marketing? Journal of Service Research, 7(1), $20-41$. https://doi.org/10.1177/1094670504266131

Lusardi, A., \& Mitchell, O. S. (2014). The Economic Importance of Financial Literacy: Theory and Evidence. Journal of Economic Literature, 52(1), 5-44. https://doi.org/10.1257/jel.52.1.5

Marisa, E. S. (2020). Pengaruh Literasi Keuangan, Promosi Uang Elektronik dan Kemudaan Penggunaan Terhadap Keputusan Penggunaan Uang Elektronik. JPEKA Jurnal Pendidikan Ekonomi, Manajemen Dan Keuangan, 4.

Mohammadyari, S., \& Singh, H. (2015). Understanding the effect of e-learning on individual performance: The role of digital literacy. Computers \& Education, 82, 11-25. https://doi.org/10.1016/j.compedu.2014.10.025

Otoritas Jasa Keuangan. (2015). Bijak Ber-Electronic Banking. Bijak Ber-Ebanking, 1-325. Retrieved from https://www.ojk.go.id/id/kanal/perbankan/berita-dan-kegiatan/publikasi/Pages/OJK-Luncurkan-BukuBijak-Ber-eBanking.aspx

Ramadhan, R., \& Herianingrum, S. (2017). Persepsi Kemudahan Penggunaan, Persepsi Kredibilitas, dan Persepsi Harga Terhadap Niat Nasabah Menggunakan Layanan Mobile Banking (Studi Kasus Pada Bank Syariah Mandiri Surabaya). Jurnal Ekonomi Syariah Teori Dan Terapan, 4(6), 478. https://doi.org/10.20473/vol4iss20176pp478-492

Ramdani, D. (2020). Pengaruh Literasi Keuangan, Digital marketing, Brand Image dan Word of mouth Terhadap Minat Generasi Z pada Bank Syariah. In Repository.Uinjkt.Ac.Id. Retrieved from http://repository.uinjkt.ac.id/dspace/handle/123456789/52986

Sigar, J. F. (2016). the Influence of Perceived Usefulness, Perceived Ease of Use and Perceived Enjoyment To Intention To Use Electronic Money in Manado. Jurnal EMBA: Jurnal Riset Ekonomi, Manajemen, Bisnis Dan Akuntansi, 4(2), 498-507. https://doi.org/10.35794/emba.v4i2.13083

Sugiyono. (2017). Metode Penelitian Kuantitatif, Kualitatif Dan R\&D. Bandung: Alfbeta.

Susilawaty, L., \& Nicola, N. (2020). Pengaruh layanan perbankan digital pada kepuasan nasabah perbankan. Jurnal Manajemen Maranatha, 19(2), 179-190. https://doi.org/10.28932/jmm.v19i2.2478

Vebiana, V. (2018). Perbankan Digital , Pengalaman Pelanggan, dan Kinerja Keuangan Bank Syariah. 9th Industrial Research Workshop and National Seminar, 747-751. https://doi.org/https://doi.org/10.35313/irwns.v9i0.1145

Venkatesh, V., \& Davis, F. D. (2000). A Theoretical Extension of the Technology Acceptance Model: Four Longitudinal Field Studies. Management Science, 46(2), 186-204. https://doi.org/10.1287/mnsc.46.2.186.11926 
Yosepha Pusparisa. (2020). Survei KIC: Dompet Digital Paling Banyak Digunakan Saban Hari. Retrieved January 1, 2021, from databoks. website: https://databoks.katadata.co.id/datapublish/2020/10/28/surveikic-dompet-digital-paling-banyak-digunakan-saban-hari

Yushita, A. N. (2017). Pentingnya Literasi Keuangan Bagi Pengelolaan Keuangan Pribadi. Nominal, Barometer Riset Akuntansi Dan Manajemen, 6(1), 11-26. https://doi.org/10.21831/nominal.v6i1.14330 